\title{
Long term outcome and quality of life after open incisional hernia repair - light versus heavy weight meshes
}

\author{
Roland Ladurner ${ }^{*}$, Costanza Chiapponi, Quirin Linhuber and Thomas Mussack
}

\begin{abstract}
Background: Mesh repair of incisional hernia is superior to the conventional technique. From all available materials for open surgery polypropylene (PP) is the most widely used. Development resulted in meshes with larger pore size, decreased mesh surface and lower weight. The aim of this retrospective non randomized study was to compare the quality of life in the long term follow up (> 72 month) after incisional hernia repair with "light weight"(LW) and "heavy weight"(HW) PP meshes.
\end{abstract}

Methods: 12 patients who underwent midline open incisional hernia repair with a HW-PP mesh (Prolene ${ }^{\circledR} 109 \mathrm{~g} / \mathrm{m}^{2}$ pore size $1.6 \mathrm{~mm}$ ) between January 1996 and December 1997 were compared with 12 consecutive patients who underwent the same procedure with a LW-PP mesh $\left(V y p r o{ }^{\circledR} 54 \mathrm{~g} / \mathrm{m}^{2}\right.$, pore size 4-5 mm) from January 1998. The standard technique was the sublay mesh-plasty with the retromuscular positioning of the mesh. The two groups were equal in BMl, age, gender and hernia size. Patients were routinely seen back in the clinic.

Results: In the long term run (mean follow up $112 \pm 22$ months) patients of the HW mesh group revealed no significant difference in the SF-36 Health Survey domains compared to the LW group (mean follow up $75 \pm 16$ months).

Conclusions: In this study the health related quality of life based on the SF 36 survey after open incisional hernia repair with light or heavy weight meshes is not related to the mesh type in the long term follow up.

Keywords: incisional hernia repair, heavy weight, low weight polypropylene mesh, quality of life

\section{Background}

Hernia repair is one of the most common surgical operations with more than 50.000 incisional hernia repaired every year in Germany. Patient seek surgical repair because of physical discomfort and aesthetic reasons. Both impair their quality of life. Unfortunately some patients complain of abdominal discomfort also after the operation. Despite the surgical technique one possible factor is the type of mesh used. Polypropylene (PP) is the most widely used mesh material for hernia repair. PP meshes show a high stretch and tensile strength, five times higher than the maximal physiologic stress. The extent of the scar tissue induced by the mesh depends on the amount and structure of the

\footnotetext{
* Correspondence: Roland.Ladurner@med.uni-muenchen.de Department of Surgery Innenstadt, Ludwig-Maximilian-University of Munich, Nussbaumstr. 20. 80336 Munich, Germany
}

incorporated material and is responsible for the abdominal wall compliance $[1,2]$. In $20 \%$ of the cases heavy weight (HW) and small pore size PP meshes caused a reduction of the abdominal wall mobility ("stiff abdomen") $[3,4]$. This complication was associated with chronic abdominal pain. As a consequence macropore light weight (LW) PP meshes strong enough to resist maximal physiologic stress of the abdominal wall were developed [5]. This development resulted in a reduction of the chronic pain $[1,6,7]$. Whether macropore LW-PP meshes have also a beneficial effect on the life quality of patients in the long term outcome after open incisional hernia repair is still unclear. The objective of this study was therefore to assess the health related quality of life (HrQoL) and the long term outcome of patients with open incisional hernia repair using HW- versus LW-PP meshes. 


\section{Methods}

\section{Characteristics of the study group}

33 patients with midline open incisional hernias were operated with a heavy weight mesh (Prolene ${ }^{\circledR} 108.5 \mathrm{~g} /$ $\mathrm{m}^{2}$ pore size $1.6 \mathrm{~mm}$, Ethicon, Nordersted; Germany) between January 1996 and December 1997 and were eligible for this study. Unfortunately only 12 of them could be followed up over the years. For the comparison the next 12 consecutive patients operated with a light weight mesh (Vypro ${ }^{\circledR} 54 \mathrm{~g} / \mathrm{m}^{2}$, pore size $4-5 \mathrm{~mm}$, Ethicon, Nordersted, Germany) after January 1998 were enrolled in the study. We excluded incarcerated, lateral or parastomal hernias, hernia repair not using mesh replacement and hernia repair performed with another procedure (laparoscopic hernia repair, onlay and inlay mesh-plasty).

The standard technique consisted of laparotomy, adhaesiolysis, hernia sac resection, closure of the posterior rectus fascia and retromuscular positioning of the PP mesh. Mesh size was chosen so that the margin extended beyond the margin of the defect throughout the defect's entire circumference. The mesh overlap was at least $5 \mathrm{~cm}$. Mesh fixation was performed with interrupted PP 3/0 sutures in the midline and at the border of the mesh. The lateral mesh fixation occurred along the margin of the rectus muscle. By doing this the intercostal nerve branches were carefully preserved to avoid muscular atrophy. The anterior rectus sheath was closed with a continuous PDS 2/0 running suture loop.

Patients were routinely seen back in the clinic 3, 6 and 12 months postoperatively, then yearly thereafter. The standard follow up consisted of anamnesis, physical examination and ultrasound or MRI, when needed (anamnesis and physical examination suggestive of hernia recurrence or intestinal adhesions). The follow up could be completed in all 24 cases.

\section{Life Quality (SF36)}

We used the SF-36, a multidimensional questionnaire composed of 36 items to determine the health related quality of life [8]. The SF36 health survey consists of eight different health quality domains: physical function (10 items), role limitations due to physical functions role (4 items), bodily pain ( 2 items), general health (5 items), vitality ( 4 items), social function (2 items), role limitations due to emotional function (3 items), mental health (5 items). The results from each scale vary from 0 to 100 (worst to best possible health status). Additionally, the SF-36 Physical Component Summary (PCS), and the Mental Component Summary (MCS) scales were determined, ranging from zero (lowest well-being) to 100 (highest well-being) $[9,10]$. The SF 36 Health survey scores were compared with the age-stratified
German population. The questionnaire evaluates the negative health aspects (disease or illness) and the positives aspects (well being). The generic SF-36 was chosen instead of more specific scales like the CCS (Carolina Comfort Scale) [11] because it is the gold standard for measuring quality of life and it is validated in German language [12].

\section{Statistical analysis}

All data are presented as means and standard deviation. Differences between the intervention groups (HW vs LW PP meshes) were tested for significance using the unpaired $t$ test for quantitative parametric variables and the Mann-Withney rank sum test for quantitative non parametric variables. The comparisons were performed using STATVIEW 4.5 software (Abacus Concepts, Berkeley, CA). Significance levels were set as $\mathrm{p}<0.05$.

\section{Results}

\section{Patient characteristics}

12 patients (mean age $57.3 \pm 11.8$, range $24-80$ years) underwent sublay hernia repair with HW-PP meshes between January 1996 and December1997. The body mass index (BMI) was $29.8 \pm 3.7 \mathrm{~kg} / \mathrm{m}^{2}$ and the hernia size was $127.2 \pm 97.2 \mathrm{~cm}^{2}$. From January 1998 all patients received sublay hernia repair with a LW PP mesh. 12 consecutive patients (mean age $58.3 \pm 11.1$ years, range 28-82 years) were enrolled in the survey. The body mass index (BMI) was $28.7 \pm 3.5 \mathrm{~kg} / \mathrm{m}^{2}$ and the hernia size $226 \pm 301.5 \mathrm{~cm}^{2}$. The point plot graph shows the hernia size of the two groups (Figure 1).

There were no significant difference in age, gender, body mass index, hernia size, patient related risk factors, operation time and the length of the hospital stay (Table 1). As patient related risk factors were considered obesity (BMI > $30 \mathrm{~kg} / \mathrm{m}^{2}$ ), diabetes mellitus, steroid therapy, nutritional deficiencies, renal impairment, chemotherapy, smoking, chest problems and hepatic cirrhosis [13]. Comorbidities were also comparable between the groups (Table 2).

\section{Long term follow up}

The follow up could be completed in all 24 cases and was significant longer in the HW group (HW $112 \pm 22$ months; LW $75 \pm 16$ months).

In no case a hernia recurrence occurred. Two patients of the LW-group complained of low dragging pain during physical activity but no pain at rest (follow up 18 and 36 months respectively), whereas two patients of the HWgroup reported on abdominal pain at rest as well as in motion (16.6\%). One of these patients had a "stiff abdomen" (follow up 31 month), the other had no alteration of the abdominal wall mobility (follow up 89 month). 
Table 2 Comorbidities

\begin{tabular}{lll}
\hline & $\begin{array}{l}\text { LW mesh } \\
\left(\text { Vypro }^{\circledR}\right)\end{array}$ & $\begin{array}{l}\text { HW mesh } \\
\text { (Prolene }^{\circledR} \text { ) }\end{array}$ \\
\hline number of patients & 12 & 12 \\
cancer & 3 & 4 \\
asthma/COPD & 3 & 3 \\
heart disease & 2 & 1 \\
diabetes & 1 & 2 \\
back pain & 1 & - \\
\hline
\end{tabular}

were lower than the scores of the age-stratefied healthy German population. (Table 3 and 4).

\section{Discussion}

PP is one of the most widely used meshes in abdominal wall surgery. It elicits an intense desmoplastic reaction in tissue, accompanied initially by serous exudation and resulting eventually in the formation of a sheet of scar that uses the mesh as a scaffold for its formation $[7,14]$. This mesh integration process in the abdominal wall and extent of scar tissue are regulated by the amount and structure of the incorporated material. The heavier the mesh weight and the smaller the size of the mesh pores are, the greater the resulting amount of scar tissue. The wound healing process causes a contraction of the mesh about $40 \%$ [15]. A high inflammatory activity as in the wake of a high amount of foreign material can increase this rate up to $90 \%$ [1]. Moreover the tissue reaction is not uniform but an individual patient depending factor [16].

The initial deployment of abdominal wall meshes developed meshes with small pore size and accordingly heavy weight. The clinical consequence was an impairment of the abdominal wall compliance: so $20-38 \%$ of the patients complained of reduced flexibility of the abdominal wall ("stiff abdomen") [3,4,17]. Since chronic pain has direct impact on most of the daily activities, it's an important aspect in the outcome of hernia surgery [18]. So the health related quality of life (HrQoL) has been receiving increasingly significance in the outcome evaluation of surgical treatments in the last years [19-26].

To reduce the incidence of abdominal stiffness and chronic pain, macropore light weight PP meshes strong enough to resist maximal physiologic stress of the abdominal wall were developed [5]. The aim of this study was to investigate whether the mesh type (LW vs HW) has an impact on the "quality of life" in the long term follow up (> 72 months) after incisional hernia repair. Hypothesis was that the use of LW meshes lead to less chronic pain and therefore to a better physical, psychosocial and social well-being compared to patients with HW-meshes.

Data for the LW light weight and HW heavy weight group are presented as mean \pm standard deviation. Differences were considered significant at $\mathrm{p}<0.05$. 
Table 3 SF 36 health survey

\begin{tabular}{|c|c|c|c|c|}
\hline & $\begin{array}{l}\text { LW mesh } \\
\left(\text { Vypro }^{\circledR}\right)\end{array}$ & $\begin{array}{l}\text { HW mesh } \\
\left(\text { Prolene }^{\mathbb{B}}\right)\end{array}$ & $p$ & German normal population \\
\hline physical functioning & $64.2 \pm 26.5$ & $71.3 \pm 33.3$ & 0.570 & $83.7 \pm 19.5$ \\
\hline physical role functioning & $50.0 \pm 46.5$ & $45.8 \pm 45.0$ & 0.826 & $80.6 \pm 31.9$ \\
\hline bodily pain & $62.3 \pm 35.0$ & $67.3 \pm 31.9$ & 0.718 & $72.7 \pm 27.3$ \\
\hline general health perceptions & $50.6 \pm 26.5$ & $49.3 \pm 21.5$ & 0.894 & $61.0 \pm 19.1$ \\
\hline vitality & $48.3 \pm 13.4$ & $51.3 \pm 10.3$ & 0.555 & $61.2 \pm 17.3$ \\
\hline social role functioning & $74.0 \pm 22.9$ & $70.8 \pm 21.5$ & 0.734 & $86.8 \pm 18.0$ \\
\hline emotional role functioning & $47.2 \pm 48.1$ & $77.8 \pm 32.8$ & 0.084 & $88.9 \pm 26.9$ \\
\hline mental health & $60.3 \pm 29.3$ & $70.3 \pm 12.4$ & 0.288 & $72.4 \pm 16.1$ \\
\hline
\end{tabular}

The first four domains describe the physical, the last four the mental health status. The results from each scale vary from 0 to 100 (worst to best possible health status). The scores are compared to the age-stratified German population (Bullinger M, Kirchberger I. S36 Fragebogen zum Gesundheitszustand Holzgreve 1998) Data for the LW light weight and HW heavy weight group are presented as mean \pm standard deviation. Differences were considered significant at $\mathrm{p}<0.05$.

As an instrument to investigate this question the SF36 Health Survey was used. This is a well validated generic health status measure as opposed to one that targets a specific age disease or treatment group [10,27,28]. The questionnaire is made of up eight-scales. Four of them describe the physical and four the mental health status. The SF 36 Health Survey has been translated in more than 50 languages and adjusted to the cultural variations $[24,29]$. For hernia patients no specific HRQoL questionnaires are available.

In our study two patients of the LW-group complained about low dragging pain during physical activity. The pain did not persist at rest. Two patients of the HW-group reported on abdominal pain at rest as well as in motion (16.6\%). The reported intensity of the pain was lower in the LW-group. However the SF36 Survey showed no significant difference in the quality of life of patients operated with a LW -or a HW -mesh in the long term follow up.

This lack of difference in the quality of life of the two groups is an interesting finding. In fact most studies investigating the life quality of patients undergoing inguinal hernia repair showed significant better results for LW meshes [30].

This is probably due to the fact that requirements for inguinal and ventral open hernia repair are different. The quality and the causes of pain following surgery are also different in inguinal and incisional hernia repair [31-33]. As a complication of inguinal hernia repair patients suffer mostly of neuropathic pain $[32,34]$. This

Table 4 Physical and mental component summary

\begin{tabular}{|c|c|c|c|}
\hline & $\begin{array}{l}\text { LW mesh } \\
\left(\text { (Vypro }^{\circledR}\right)\end{array}$ & $\begin{array}{l}\text { HW mesh } \\
\text { (Prolene }^{\circledR} \text { ) }\end{array}$ & German normal population \\
\hline$\overline{P C S}$ & $47.8 \pm 7.5$ & $49.4 \pm 7.3$ & $47.9 \pm 9.7$ \\
\hline MCS & $46.6 \pm 8.5$ & $48.8 .8 \pm 10.0$ & $51.16 \pm 8.1$ \\
\hline
\end{tabular}

PCS (physical component summary) and MCS (mental component summary) in comparison to the age-stratified German population. (Bullinger $M$, Kirchberger I. S36 Fragebogen zum Gesundheitszustand Holzgreve 1998) is due to nerve compression caused by nerve injury during surgery (suture, tacks, mesh) or by perineural fibrosis induced by the incorporated mesh. The key to avoid chronic neuropathic pain is the preservation of the nerves during surgery beside the choice of an appropriate mesh material [35].

After open incisional hernia repair dominates non neuropathic somatic pain, caused by mechanic pressure of the folded mesh or scar tissue. This pain condition is influenced by the mesh elastic properties and the amount and structure of the material used for repair [31-33]. The mesh type and structure are therefore the main reason for the abdominal wall compliance and pain in the postoperative period.

An explanation for the lack of difference in the quality of life of patients operated with a more elastic and lighter material compared to those operated with heavier and stiffer material might be that chronic pain did not have the expected influence on the daily activity of the patients.

Nikkolo et al arrived to a similar conclusion in a randomised trial comparing LW and HW meshes for inguinal hernia repair [36]. Also Conze et al found in a prospective randomized clinical trial comparing lightweight composite mesh with polyester or polypropylene mesh no difference in the SF 36 physical function scores or daily activity for the first 24 month after the operation. In this study the SF36 scores between 4 and 24 months showed no further improvement. These findings were also irrespective of the mesh type [37].

The mean age of patients undergoing incisional hernia repair was $57 \pm 11$ and $58 \pm 11$ years. The health perception changes with increasing age. So despite poorer role and physical function elderly patients have similar global health perception compared with younger individuals [38].

Another important aspect is that this study compares the quality of life following open incisional hernia repair after a longer period of time $(112 \pm 22$ and $75 \pm 16$ 
months) in opposition to most studies with a follow up of 6 to 12 months. Probably patients get used to the increased abdominal wall stiffness caused in the long term. However two patients of the heavy weight group complained of chronic pain as opposed to the low weight group where two patients complained of discomfort.

More generally the HrQoL of patients undergoing incisional hernia repair (no matter if with low or heavy weight mesh) is worse than that of the healthy population in the same age. There are several possible explanations for this. The comorbidities (cancer, heart disease, diabetes, back pain) might have influence on the quality of life. Some of those diseases or their treatments (diabetes, COPD, corticosteroid-/chemotherapy) are know to be risk factors for hernia formation. On the other hand patients with chronic disease tend to downscale their expectations for life and feel satisfied as long as they can stabilize their condition and be free from complication and aggravation [39].

The study has several limitations. First the group size is small. Starting with January 1998 heavy weight meshes were no longer used in our department. Additionally due to the long term follow up also the drop out rate was high. Therefore it was not possible to include more patients in this study. This reduces the power of the statistic.

Second limit is the different length of observation of the groups. However the shortest median observation time is 75 months. In our experience patients symptoms do not change significantly more than 5 years postoperatively.

Another limitation is the method of measuring the quality of life. A hernia specific scale would be preferable. Such a validated instrument though was not available at the time of the study and does not exist up to now in German language. For this reason the SF-36 was used.

\section{Conclusions}

In this study the health related quality of life based on the SF 36 survey after open incisional hernia repair with light or heavy weight meshes is not related to the mesh type in the long term follow up.

\footnotetext{
Authors' contributions

$\mathrm{RL}$ and $\mathrm{TM}$ conceived this study, $\mathrm{RL}, \mathrm{QL}$ and $\mathrm{CC}$ acquired and interpreted the data, $R L$ and CC wrote the manuscript, TM revised the manuscript critically; all authors have given final approval of the version to be published.
}

\section{Competing interests}

The authors declare that they have no competing interests.
References

1. Schumpelick V, Klosterhalfen B, Muller M, Klinge U: Minimized polypropylene mesh for preperitoneal net plasty (PNP) of incisional hernias. Chirurg 1999, 70:422-430.

2. Welty $G$, Klinge $U$, Klosterhalfen $B$, Kasperk $R$, Schumpelick V: Functional impairment and complaints following incisional hernia repair with different polypropylene meshes. Hernia 2001, 5:142-147.

3. Read RC, Barone GW, Hauer-Jensen M, Yoder G: Properitoneal prosthetic placement through the groin. The anterior (Mahorner-Goss, RivesStoppa approach. Surg Clin North Am 1993, 73:545-555.

4. Klinge U, Prescher A, Klosterhalfen B, Schumpelick V: Development and pathophysiology of abdominal wall defects. Chirurg 1997, 68:293-303.

5. Klinge U, Klosterhalfen B, Conze J, Limberg W, Obolenski B, Ottinger AP, Schumpelick V: Modified mesh for hernia repair that is adapted to the physiology of the abdominal wall. Eur J Surg 1998, 164:951-960.

6. Cobb WS, Kercher KW, Heniford BT: The argument for lightweight polypropylene mesh in hernia repair. Surg Innov 2005, 12:63-69.

7. Bringman S, Conze J, Cuccurullo D, Deprest J, Junge K, Klosterhalfen B, Parra-Davila E, Ramshaw B, Schumpelick V: Hernia repair: the search for ideal meshes. Hernia 2010, 14:81-87.

8. Bullinger M: Assessment of health related quality of life with the SF-36 Health Survey. Rehabilitation (Stuttg) 1996, 35:XVII-XXVII.

9. Thaler K, Dinnewitzer A, Mascha E, Arrigain S, Weiss EG, Nogueras JJ, Wexner SD: Long-term outcome and health-related quality of life after laparoscopic and open colectomy for benign disease. Surg Endosc 2003 , 17:1404-1408.

10. Ware JE Jr, Sherbourne CD: The MOS 36-item short-form health survey (SF-36). I. Conceptual framework and item selection. Med Care 1992, 30:473-483.

11. Heniford BT, Walters AL, Lincourt AE, Novitsky YW, Hope WW, Kercher KW: Comparison of generic versus specific quality-of-life scales for mesh hernia repairs. J Am Coll Surg 206:638-644.

12. Bullinger M: German translation and psychometric testing of the SF-36 Health Survey: preliminary results from the IQOLA Project. International Quality of Life Assessment. Soc Sci Med 2008, 41:1359-1366.

13. El Khadrawy OH, Moussa G, Mansour O, Hashish MS: Prophylactic prosthetic reinforcement of midline abdominal incisions in high-risk patients. Hernia 2009, 13:267-274

14. Sergent F, Desilles N, Lacoume Y, Tuech JJ, Marie JP, Bunel C: Biomechanical analysis of polypropylene prosthetic implants for hernia repair: an experimental study. Am J Surg 2010, 200:406-412.

15. Klinge U, Klosterhalfen B, Muller M, Ottinger AP, Schumpelick V: Shrinking of polypropylene mesh in vivo: an experimental study in dogs. Eur $J$ Surg 1998, 164:965-969.

16. Schachtrupp A, Klinge $U$, Junge $K$, Rosch $R$, Bhardwaj RS, Schumpelick V: Individual inflammatory response of human blood monocytes to mesh biomaterials. Br J Surg 2003, 90:114-120.

17. Schmidbauer S, Ladurner R, Hallfeldt KK, Mussack T: Heavy-weight versus low-weight polypropylene meshes for open sublay mesh repair of incisional hernia. Eur J Med Res 2005, 10:247-253.

18. Poobalan AS, Bruce J, King PM, Chambers WA, Krukowski ZH, Smith WC: Chronic pain and quality of life following open inguinal hernia repair. $\mathrm{Br}$ J Surg 2001, 88:1122-1126.

19. Barrat C, Seriser F, Arnoud R, Trouette P, Champault G: Inguinal hernia repair with beta glucan-coated mesh: prospective multicenter study (115 cases)-preliminary results. Hernia 2004, 8:33-38.

20. Lawrence K, McWhinnie D, Jenkinson C, Coulter A: Quality of life in patients undergoing inguinal hernia repair. Ann R Coll Surg Engl 1997, 79:40-45.

21. Thaler K, Dinnewitzer A, Oberwalder M, Weiss EG, Nogueras JJ, Wexner SD: Assessment of long-term quality of life after laparoscopic and open surgery for Crohn's disease. Colorectal Dis 2005, 7:375-381.

22. Woodcock SA, Watson DI, Lally C, Archer S, Bessell JR, Booth M, Cade R, Cullingford GL, Devitt PG, Fletcher DR, Hurley J, Jamieson GG, Kiroff G, Martin CJ, Martin IJ, Nathanson LK, Windsor JA: Quality of life following laparoscopic anterior 90 degrees versus Nissen fundoplication: results from a multicenter randomized trial. World J Surg 2006, 30:1856-1863.

23. Zieren J, Zieren HU, Wenger F, Muller JM: Repair of inguinal hernia in the elderly. Results of the plug-and-patch repair with special reference to quality of life. Chirurg 2000, 71:564-567. 
24. Korolija D, Sauerland S, Wood-Dauphinee S, Abbou CC, Eypasch E, Caballero MG, Lumsden MA, Millat B, Monson JR, Nilsson G, Pointner R, Schwenk W, Shamiyeh A, Szold A, Targarona E, Ure B, Neugebauer E: Evaluation of quality of life after laparoscopic surgery: evidence-based guidelines of the European Association for Endoscopic Surgery. Surg Endosc 2004, 18:879-897.

25. Poelman MM, Schellekens JF, Langenhorst BL, Schreurs WH: Health-related quality of life in patients treated for incisional hernia with an onlay technique. Hernia 2010, 14:237-242.

26. Wassenaar E, Schoenmaeckers E, Raymakers J, van der PJ, Rakic S: Meshfixation method and pain and quality of life after laparoscopic ventral or incisional hernia repair: a randomized trial of three fixation techniques. Surg Endosc 2010, 24:1296-1302.

27. McHorney CA, Ware JE Jr, Raczek AE: The MOS 36-Item Short-Form Health Survey (SF-36): II. Psychometric and clinical tests of validity in measuring physical and mental health constructs. Med Care 1993, 31:247-263.

28. McHorney CA, Ware JE Jr, Lu JF, Sherbourne CD: The MOS 36-item ShortForm Health Survey (SF-36): III. Tests of data quality, scaling assumptions, and reliability across diverse patient groups. Med Care 1994, 32:40-66

29. Alonso J, Ferrer M, Gandek B, Ware JE Jr, Aaronson NK, Mosconi P, Rasmussen NK, Bullinger M, Fukuhara S, Kaasa S, Leplege A: Health-related quality of life associated with chronic conditions in eight countries: results from the International Quality of Life Assessment (IQOLA) Project. Qual Life Res 2004, 13:283-298.

30. Khan LR, Liong S, de Beaux AC, Kumar S, Nixon SJ: Lightweight mesh improves functional outcome in laparoscopic totally extra-peritoneal inguinal hernia repair. Hernia 2010, 14:39-45.

31. Heise CP, Starling JR: Mesh inguinodynia: a new clinical syndrome after inguinal herniorrhaphy? J Am Coll Surg 1998, 187:514-518.

32. Amid PK: Causes, prevention, and surgical treatment of postherniorrhaphy neuropathic inguinodynia: triple neurectomy with proximal end implantation. Hernia 2004, 8:343-349.

33. Cunningham J, Temple WJ, Mitchell P, Nixon JA, Preshaw RM, Hagen NA: Cooperative hernia study. Pain in the postrepair patient. Ann Surg 1996, 224:598-602.

34. Pappalardo G, Frattaroli FM, Mongardini M, Salvi PF, Lombardi A, Conte AM, Arezzo MF: Neurectomy to prevent persistent pain after inguinal herniorraphy: a prospective study using objective criteria to assess pain. World J Surg 2007, 31:1081-1086.

35. Alfieri S, Rotondi F, Di Giorgio A, Fumagalli U, Salzano A, Di Miceli D, Ridolfini MP, Sgagari A, Doglietto G: Influence of preservation versus division of ilioinguinal, iliohypogastric, and genital nerves during open mesh herniorrhaphy: prospective multicentric study of chronic pain. Ann Surg 2006, 243:553-558.

36. Nikkolo C, Lepner U, Murruste M, Vaasna T, Seepter H, Tikk T: Randomised clinical trial comparing lightweight mesh with heavyweight mesh for inguinal hernioplasty. Hernia 2010, 14:253-258.

37. Conze J, Kingsnorth AN, Flamnet JB, Simmermacher R, Arlt G, Langer C, Schippers E, Hartely M, Schumpelick V: Randomized clinical trial comparing lightwight composite mesh with polyester or polypropylene mesh for incisional hernia repair. Br J Surg 2005, 92:1488-1493.

38. Mangione CM, Marcantonio ER, Goldman L, Cook EF, Donaldson MC, Sugarbaker DJ, Poss R, Lee TH: Influence of age on measurement of health status in patients undergoing elective surgery. J Am Geriatr Soc 1993, 41:377-383.

39. Wang HM, Beyer M, Gensichen J, Gerlach FM: Health-related quality of life among general practice patients with differing chronic disease in Germany: Cross sectional survey. BMC Public Health 2008, 8:246-258.

\section{Pre-publication history}

The pre-publication history for this paper can be accessed here: http://www.biomedcentral.com/1471-2482/11/25/prepub

doi:10.1186/1471-2482-11-25

Cite this article as: Ladurner et al:: Long term outcome and quality of life after open incisional hernia repair - light versus heavy weight meshes. BMC Surgery 2011 11:25.

\section{Submit your next manuscript to BioMed Central and take full advantage of:}

- Convenient online submission

- Thorough peer review

- No space constraints or color figure charges

- Immediate publication on acceptance

- Inclusion in PubMed, CAS, Scopus and Google Scholar

- Research which is freely available for redistribution

Submit your manuscript at www.biomedcentral.com/submit 